\title{
Psychology University Services, the Health and Social Welfare Policies
}

\author{
Maria Aparecida de França Gomes ${ }^{1}$ \\ Programa de Pós graduação em Psicologia, Universidade Federal do Rio Grande do Norte, \\ Natal, RN, Brasil, \\ Serviço Integrado de Psicologia da Universidade Potiguar - Laureate International \\ Universities, Natal, RN, Brasil \\ Magda Dimenstein \\ Departamento de Psicologia da Universidade Federal do Rio Grande do Norte, \\ Natal, RN, Brasil
}

\begin{abstract}
The current study approaches the practices developed by Psychology Universities Services (SEP - Serviços Escola de Psicologia) and used to train psychologists in health and social welfare policy. The experiment comprised 57 interns and 24 graduates from 4 SEP in Rio Grande do Norte State (RN). Participants anonymously answered a survey distributed in loco, among the interns, and virtually, among the egresses. A questionnaire was handed to curricular internship students in each SEP in 2012, and it was sent via google platform to the 2010 and 2011 graduates by the Regional Council of Psychology (CRP-17). Results indicate the prevalence of the care model based on traditional clinical Psychology, although it is possible to see its slight association with health and social assistance networks. Different types of practices were detected in addition to psychotherapy and psychological assessments. However, the SEP are still isolated, either from the other courses composing the list of professional categories that operate in this scope or from health and social assistance services.
\end{abstract}

Keywords: Psychology university services, psychologist graduation, health policy, social welfare policy.

\section{Serviço Escola de Psicologia e as Políticas de Saúde e de Assistência Social}

\section{Resumo}

O presente artigo tem como objetivo discutir as práticas desenvolvidas nos Serviços Escola de Psicologia (SEP), na perspectiva da formação de psicólogos para as políticas de saúde e assistência social. Participaram desta pesquisa 57 estagiários e 24 egressos de quatro SEP no Rio Grande do Norte (RN). Foi utilizado como instrumento um questionário, aplicado com estudantes que estavam realizando estágio curricular em cada um dos SEP no ano de 2012. Esse mesmo instrumento foi enviado pelo Conselho Regional de Psicologia (CRP-17), através da plataforma Google, para os egressos concluintes em 2010 e 2011. Os resultados apontam para a predominância do modelo de atenção baseado na psicologia clínica tradicional, embora a articulação com as redes de saúde e de assistência social já possa ser timidamente visualizada. Diferentes modalidades de práticas também foram detectadas, para

Mailing address: Av. Capitão-Mor Gouveia, 2488, A3, Apto. 75, Cidade da Esperança, Natal, RN, Brazil 59070-400. Phone: (84) 98815-5339. E-mail: cidafrance@gmail.com 
além das psicoterapias e avaliação psicológica. Contudo, os SEP ainda permanecem isolados, seja dos demais cursos que compõem o rol de categorias profissionais que atuam nesse âmbito, seja dos serviços de saúde e de assistência social.

Palavras-chave: Serviço escola de psicologia, ensino da psicologia, política de saúde, política de assistência social.

\section{Servicio Escuela de Psicología y las Políticas de Salud y Bienestar Social}

\section{Resumen}

En el artículo se discute las prácticas desarrolladas en los servicios escuela de psicología con el propósito de formar psicólogos para actuar en las políticas de salud y bienestar social. Participaron de la investigación 57 practicantes y 24 egresos de cuatro SEP en Rio Grande del Norte (RN). Se utilizó como instrumento un cuestionario junto a los estudiantes que se estaban desarrollando prácticas en cada uno de los SEP en 2012. Este instrumento fue enviado a través de la plataforma Google por el Consejo Regional de Psicología (CRP-17) para los graduados de 2010 y 2011. Los resultados apuntan para la predominancia del modelo de atención basado en la psicología clínica tradicional. Sin embargo la articulación con las redes de salud y bienestar social ya pueda ser tímidamente visualizada. Distintas modalidades de prácticas también fueron detectadas además de las psicoterapias y evaluación psicológica. Pero, los SEP aún están aislados, sea de los otros cursos que componen la lista de categorías profesionales que actúan en ese ámbito, sea de los servicios de salud y de bienestar social.

Palabras clave: Servicio escuela de psicologia, educación en psicologia, política de salud, política de bienestar social.

The present study is part of a doctoral thesis in development, which investigates the model and the practices performed by the Psychology University Services (SEP) of education institutions of Rio Grande do Norte. We have selected this field, first, for it being a privileged learning space for psychologists in their entrance in the workforce. In addition, it is also perceivable the need to reinvent this institution to break its isolation from other courses that form professionals to work in public health and social service networks, as well as the informal relation that they maintain with psychosocial care networks.

Facing the scarcity of studies in the perspective of problematizing the role of SEP in the operationalization of the principles and guidelines of public health and social service policies, we endeavored this investigation from the experience of the authors in health management, working in health institutions and as supervising instructors of internship and coordinating the SEP, seeking to contribute with this debate.

\section{Considerations on the Formation on Psychology to Operate in Health Policies and Social Services}

Many aspects that form the consolidation of the psychologist's profession have been drawing the attention of scholars, from the search of a professional identity to the need of constant upgrading imposed by the demands of modern society, which has produced changes both in formation and professional practice. We know that Psychology incorporated to neoliberalism has contributed in a unquestionable way with the production and strengthening of social control, ordering and maintenance, being targeted by the market, as it may be observed in the increasing number of private Higher Education Institutions (IES) operating in the country, as well as what has become associated to the sector in terms of disengagement with social problematics produced by social hegemonic forces. 
Currently,

the profession of a psychologist is a regulated and institutionalized occupational space, integrated to society's dynamic by significant and increasing commercial demand [emphasis added] in almost all fields of activity in which people work, as subject and as object [emphasis added] of attention and study. (Malvezzi, 2010, p. 18)

There was a growth of the profession and graduating institutions, after the decade of 1970 , causing formation quality to be questioned. In these fifty years of profession, the Brazilian society has been marked by economic, social and political changes, demanding the repositioning of professionals of all areas of work, and especially of the psychologist, mainly referring to enlarging the field of work, the establishment and creation of new technologies, of new manners of intervention and to conceive subjectivity production methods.

Some practices, out of context and uncompromised with the social needs demanded by the Brazilian population, are attributed to the formation in Psychology, practices base in unhistorical and abstract conceptions, without any link with the social (Abbad \& Mourão, 2010; Bernardes, 2007; Dimenstein, 1998; Dimenstein \& Macedo, 2010; Lo Bianco, Bastos, Nunes, \& Silva, 1994; Macedo \& Dimenstein, 2011; Spink, 2003; Yamamoto, 2007). This formation has been the main hub of ill-formed professionals, intellectually and professionally, according to Mello and Patto (2008), which act, many times, in a violent manner.

In this sense, it is questioned: what are the challenges that present today to Psychology? We consider that the education has "long-term effects and it is not easily changed" (Maturana, 2005, p. 29) and that the educational practices interfere in the ways of life and work. In this manner, we inquire: what are the commitments that Psychology has assumed? What tendencies are being defined with a stronger force in the reality of formation courses?

The commitment of psychologists in transformation movements in the Brazilian society is recognizable, more specifically in Health Reform, also in the Psychiatric Reform and the Anti-Asylum Movement, and the active participation in National Health Conferences, more significantly from the 1980s (Yamamoto, 2007), events that, according to Bernardes (2010, p. 106), "had timid effects in the formation of the psychologist". However, even though the effects are timid, it is observed the construction of a "new social position for Psychology and its presence in the field of public policies and social practices" (Dimenstein \& Macedo, 2012, p. 237), which urges for a qualitatively different formation.

Moreover, we agree with Ceccim and Feuerwerker (2004) when they report that the formation of health professionals - and we add here social workers - is still dissociated from the debate on social care and control. In Psychology, an organicist formation still prevail. In Social Welfare, there is still a concern regarding the escape from philanthropic bases that gave birth to the profession, and a certain legalism predominates inside the practices. Social control is still a poorly debated theme inside the academic formation of health care.

How to escape from the individualizing comfortable common place, unhistorical and out of context? How to break away with the ethnocentric, Universalist and naturalist concepts of human nature, and how demystify the alleged scientific neutrality sought during the construction of knowledge? How to work with the demands of the rights to integral health and human rights without falling into the individual/social dichotomy?

If these demands have become part of the "psych" universe of Brazil for at least twenty years, we inquire if the formation has been configured as a space that offers answers to such challenges. Has the superior education system, through its agents, followed the new professional configuration required by the Government? More specifically, have University Services upgraded its practices to be inserted in social welfare and health networks? 


\section{The Psychology University Services and its Performance in Public Policies of Social Welfare and Health Care}

The studies on SEP were exposed first in 1983 and came up questioning its effectiveness, efficiency and efficacy, assuming a pessimist future for these institutions (Silvares, 1996). However, there is a number of studies that present the practices developed in these institutions, focusing themes related to clinic Psychology, as observed in the annals of the Simpósio de Pesquisa e Intercâmbio Científico da Associação Nacional de Pesquisa e Pós-graduação em Psicologia - ANPEPP (Symposium of Research and Scientific Interchange), held in 2008, in NatalRN (Silvares, 2008).

The SEP were created from a legal obligation of existence as a space of professional practices of the psychologic future, and not as need from the population in demanding psychologic services (Boeckel et al., 2010; Melo-Silva, Santos, \& Simon, 2005; Nunes, Campezatto, Cruxên, \& Savalhia, 2006). They were considered crucial for the functioning of Psychology courses, since the acknowledgement of the profession inside Brazil, in 1962. Since then its objective is to be a space to exercise professional practices. They were contemplated by the Law n. 4.119/62, which institutes that each Psychology course should provide ". . . clinical services and applications to education and work ..." (1962). The law mentioned before legitimated the psychological work, distributed in three key areas: clinic, organizational and educational. It consolidated, in this manner, the formation space as clinic work and transported this model to the remaining areas: educational area and organizational area.

More recently, the Resolution n. 8, of May 7, 2004, instituted the Curricular Guidelines of Psychology graduation courses, and also sets, in its Article 25, the installation of a Psychology Service to attend "the needs for the formation of the psychologist, congruent with the competences that the course wants to develop in the student and the demands of a community psy- chologic service in which it is inserted" (Conselho Nacional de Educação, Câmara de Educação Superior, 2004).

We also observed that both standardizations, even with the change of name from University Clinic to University Services, consider it a practice location, and the first formulation makes clear the overlap of a clinic and the second one, although it has advanced, does not point to interdisciplinary practices and/or for a Psychology Service integrated to the networks organized by social policies. In this manner, the "community psychologic service in which it is inserted" leaves the practice location undefined, having traces of the psychologic care based on the liberal private model.

Considering the legislation and, foremost, the many studies made that emphasize the individual care disconnected from public policies, we must consider the existence of some few publications that question this model. One of them is on the Serviço de Atendimento Psicológico (SAP - Psychologic Care Service) of the Psychology College of Pontificia Universidade Católica do Rio Grande do Sul (PUCRS), which in 2005, "allowed the practice of activities of primary prevention inside the community and the direct contact with groups inside their contexts" (Boeckel et al., 2010, p. 43).

As Bernardes (2007) affirms, even though the discussion on the formation of psychologists for the work in social policies began in the decade of 1980, particularly health policies, the SEP is still forming psychologists to work as liberal professionals. This period coincides with an important growth of the category and of formation agencies, as well as the expansion of areas and spaces of work (Bastos \& Gomide, 1989; Bastos \& Gondim, 2010; Conselho Federal de Psicologia [CFP], 1988, 1992, 1994; Dimenstein, 1998, 2000; Yamamoto 2001, 2012; Yamamoto \& Oliveira, 2011; Yamamoto, Siqueira, \& Oliveira, 1997). For over 20 years, the category has assumed some characteristics, also highlighted by the mentioned researchers: the tendency of paid work, the poor working conditions and the deterioration of income, concentrating $40 \%$ of the professionals in the public sector, linked to 
social policies, and $27.9 \%$ in the health sector. However, they evince that psychologists in public institutions perform majorly test applications and psych diagnosis (Yamamoto, 2012).

The data above is very concerning, mainly considering that the majority of professionals linked to the public sector is inserted in some component of the Sistema Único de Saúde (SUS - Unified Health System) and/or the Sistema Único de Assistência Social (SUAS Unified System of Social Service). Further, the activities related to psychologic evaluation with test applications reveal what Bernardes and Menengon (2007) have pointed: the profile of the Brazilian psychologist has characteristics from their own history, for "since the very beginning in Brazil, the Psychology has hegemonic voices that produce a kind of formation always linked to Applied Psychology, originated from the Brazilian Psychology" (Bernardes \& Menengon, 2007, p. 14).

With the institutionalization of SUS, from the reorganization of national health policies in 1988 and of SUAS in 2005, some criticism was directed to these hegemonic voices present in the formation of the psychologist, as well to psychologic practices, indicating the need to redefine the professional profile heavily marked by the biomedical-private-liberal ideal. Both SUS and SUAS share the same principles and guidelines, seeking to ensure some level of social security, be it from actions that promote health, treatment and rehabilitation, be it with actions that ensure and promote social rights, with the prevention and protection from the so-called social risks (Menicucci, 2002).

For this purpose, these policies require a new kind of professional, which possess more abilities and skills to develop assistance resources suitable to the user population, culturally sensitive and effective. However, it is observed that, as pointed by Yamamoto (2012) and corroborated by other authors (Bardagi, Bizarro, Andrade, Audibert, \& Lassanc, 2008; Dimenstein, 1998; Dimenstein \& Macedo, 2012; Noronha, 2003; Paulin \& Luzio, 2009; Pazeto, 2005; Yamamoto et al., 2003), that the classic profile seems to have suffered little changes during the years and that it is still possible to find the psychologist that works with mirrored images from the medical care model, "with an individualized work, anchored in not userfocused and vertical relations, in interventions poorly diversified, circumscribed to complaints and targeted to the treatment of symptoms" (Dimenstein \& Macedo, 2012, p. 237).

In this context, we may ask: what is the role of the SEP in the formation process and in what manner they have operated in conforming professional practices, especially of this range of psychologists that became part of technical teams linked to SUS and SUAS? In the context of graduation, SEP were always an important place, since they are obligatory places for the operation of Psychologist courses. They represent a privileged field of practices, and until recently, the single field of practices. However, important criticism exist on this academic resource, as to its limits in the qualification of the psychologist in relation to the work in various contexts, for example, in health policies and social assistance. There are criticism in relation to the resource, in the educational (model) point of view and it reach, as recorded by Melo-Silva et al. (2005).

Due to this scenario, we performed this research with the objective to know the operation of the SEP of Psychology Superior Education Institutions in the city of Natal. This study was developed in four University Services of Psychology courses of Superior Education Institutions (IES) of Rio Grande do Norte, together with professors, interns and graduates. This article has as objective to present the results referring to the characterization of these SEP and their effects on the professional work in social policies, according to the evaluation of interns and graduates.

\section{Method}

This study is part of a broader qualitative research, of the observation-interventional type, performed together with course managers, academic supervisors, higher education technicians, interns and graduates of the 4 SEP of the city of 
Natal/RN. The inclusion criterion of these participants took into consideration the residence time in the University Service, once they should have been working or had worked (graduates) for at least six months.

This study seeks to present specifically the result of the stage preformed with interns and graduates from the courses and the documentary research (sites and folders) about the characteristics of the SEP.

We use as data collection tool an anonymous survey, applied on-site to the interns and online to the graduates referring to 2010 and 2011. In the case of the interns, the survey were delivered in an envelope at the reception of each SEP during the second semester of 2012, and were collected after a period of approximately two months. Concerning the graduates, an online survey was made available, which was forwarded through the Regional Council of Psychology 17 to those registered to this Council during the year of 2011 (graduates of 2010 and 2011).

Such survey focused on the following aspects: activities offered of SEP; activities developed by the intern/graduate; relation between the contents related to the formation of the psychologist and the practices developed in the University Service; the relation of the SEP with the health policies and social assistance; the level of satisfaction with the operation of SEP and the contribution to the professional formation; suggestions to the (re)structuring and operation of the SEP.

The on-site survey had an Informed Consent Term (Termo de Consentimento Livre e Esclarecido [TCLE]), informing about the research, which was accepted for all institutions involved. The online survey presented an automatic TCLE for the response, approved by the CRP 17, or in other words, if the psychologist (graduate) responded the survey, he was automatically formalizing their consent as to the use of the information to research ends.

Twenty four surveys were answered by the graduates of 2010 and 2011 and 57 by the interns of 2012 from three of four SEP. In one of the SEP, no interns answered to the survey, as well as no graduate of the same institution answered to the survey sent by the Regional Council of Psychology.

\section{Results and Discussion}

\section{Organization and Operation of the Psychology University Services}

The SEP from the IES of Rio Grande do Norte are directly linked to the Psychologist courses of the education institutions, with the exception of one institution that does not has a direct link with the course, being subordinated and linked directly to an administrative center of various courses, having some autonomy in relation to the course coordination. It is noted that this University service was the first of RN, being created even before the installation of the first course of psychology of RN, in 1965 (Mendes, n.d.).

In the presentation of the results, each SEP will be named of SEP 1, SEP 2, SEP 3 and SEP4. As to physical space, all SEP have reception, and SEP 3 and SEP 4 have receptionists exclusively for the Psychology course. At the SEP 1 and SEP 2 , there is a reception for Psychology students and of other courser of the institution that come for service, this being offered at the same space. As to these courses, there is a shared reception between Social Service and Law (SEP 1) and another for Nursing, Physiotherapy and Nutrition (SEP 2). Each of these SEP has coordination rooms, individual attendance, play therapy, group activities, intern's room and supervision rooms. In two SEP, there are rooms destined to organizational attendance (consulting etc.), but in the other service, in addition to the already mentioned space, there are two rooms for group activities, observation rooms with mirrors and an audio service that serve to the group activities and the play therapy, and exclusive room for intern interaction and a room for a Social and Community Psychology center.

As to working hours, 2 SEP operate on three shifts (morning, afternoon and night) and 2 in 2 shifts (morning and afternoon). The attended population is varied, and low-income population is predominant, of up to one minimum wage salary. The teams are composed, majorly, by 
graduated psychologists that work as field supervisors technicians and academic supervising professors, except in a Service in which a field supervisor is also the coordinator of the University Service (SEP 2), from which we do not have interns that participated in the research.

The interns from the remaining SEP receive two types of supervision, field supervision and academic supervision. Field supervision is performed by professional psychologist, hired by the IES to follow-up with the interns in the daily routine at the University Services to clarify the behavior performed in reception, shifts and triages in the Services. In addition, field supervisors help in preparing psychologic documents, when needed, to establish formal contact with other institutions, performing, in this manner, technical orientation in the daily practice of the Services. The academic supervision is performed by professors from the course, weekly, and by intern groups. This kind of supervision by the supervising professor encompasses hearing the report of practices developed by interns and technical, theoretical and ethical orientation for the development of the internship, since in the academic supervision each intern reports their practices, as the supervisor orients the reflection and evaluates the practice. According to Oliveira et al. (2014, p. 2), the supervision performed at the Psychology University Services "is one of the important pillars that support the field of formation".

From the University Services researched, only two of them have more interns that count with both modalities of supervision, field supervision and academic supervision. In relation to this aspect, what comes to attention is that the Service with the least quantity of interns is the one that has the largest contingent of hired psychologists, but these do not perform field supervision, they only attend to the population.

Each researched SEP has a different manner to record their directives, for example: SEP 1 made a folder, SEP 2 and SEP 3 indicated the IES website and the SEP 4 quoted the regulation of the University Service. Considering this reality, it may be affirmed that what is common to these documents is the availability of the service to the students of the Psychology course so they can perform their practices, with an emphasis on health and clinic. The directives (principles and special concepts) to the characterization of each SEP are not clear; nonetheless, each service represents a list of activities/services to be offered to the internal and external community to which they are linked.

The SEP is part of the pedagogical project of the researched Psychology courses, meeting the standards of the legislation, and more specifically to the National Directives for Psychology Courses (Ministério da Educação, 2011), as previously mentioned. In the analyzed documents from each SEP, neither its directives nor its political-pedagogical alignment is made evident; inasmuch as it is listed a roster of the activities developed in which the individual care is common to all. In one of them (SEP 3), the psychoanalysis is referred as one of the main lines of operation.

Some SEP are operating in spaces common to other courses, but do not present an integrated and systematized work, as the line of work or directive. The developed practices are instrumental and the formation also occurs in this manner, from a theoretical approach that serve to the traditional psychologic work of psychotherapy, without the introduction of various knowledge for the demands, as for example the field of collective health. One of the reasons for this scenario may be related with the possible lack of inclusion of the SEP in the assistance networks of public policies.

The physical condition of the SEP are good, in general, but the operation mode does not promote the use of these spaces integrated to other courses, specifically in the case of the two services that have space sharing. Both SEP that have their own space, separated from other courses, also have physical space that could be shared in the perspective of integrating knowledge and practices.

The interns and graduates link themselves to the SEP by the various modalities of internships (professional obligatory internship and non-obligatory internship) and of research, as well through extension activities and practices of 
other curricular subjects. The majority of them started their activities in the last year of course, when they should participate in the professional internship. Concerning the activities of research, it is verified a low expressive amount of activities performed by interns and graduates.

The SEP are considered, in the institutional documents of their respective courses, as spaces to perform academic extension that offer assistance activities to the population internal and external to the IES. However, few interns answered that they participate in academic extension in these spaces as part of their professional internships. In this sense, only $17.5 \%$ of the interns and $12.5 \%$ of the graduates that participated in the research consider that they established a link with the SEP of the institution in which they are part of, through extension projects.

The practice of performing researches in the SEP is very recommended (Marturano, Silvares, \& Oliveira, 2014; Romaro \& Capitão, 2003; Silvares, 2006). This modality of formation is part of the tripod of superior education, along with teaching and extension. However, in Rio Grande do Norte, the research has not been contemplated in an active way, since only $13.5 \%$ of interviewed interns and $4.1 \%$ of interviewed graduates affirmed that they perform or had performed research at the SEP, considering that in only one of them the research was mentioned as a manner of linking the intern to the service.

According to almost all interns and graduates, the individual psychologic care is the main developed activity in various modalities, such as reception, triage, psychologic counseling and psychotherapy. There are services that amplify their activities providing to the student the relocation to social devices of the community such as schools, Social Assistance Referral Center (CRAS), Specialized Social Assistance Referral Center (CREAS), health units, and other devices available, through agreements, to the IES. However, the realization of obligatory internships, in three of the IES occurs, mainly, in the service linked to the IES, since the activities offered to the population are developed eminently by interns. Only one of the institutions, among the four institutions researched, the SEP activities are performed by technicians, in addition to the students of the course, with the aggravating circumstance that in this service there is not any interaction between interns and the technical staff. This distance between the psychologists hired by the IES and the interns does not help in the formation in Psychology, since there is no transmission or contribution of these professionals as to education, research and the extension activities performed by the interns.

Boeckel et al. (2010) point that, in addition to the clinical activities common to many SEP, there are others that develop practices set in the Community Social Psychology, Health Psychology, Collective Psychology, Organization and Work Psychology, among other modalities. At the SEP in Rio Grande do Norte, we observe the predominance of clinic and a timid realization of activities in the remaining fields/areas of Psychology. The service that presented the largest variety of practices, apart from clinic, is the one with the largest number of interns. This fact suggests that the demand for internship locations in various areas and the competition for these locations among the Psychology courses of the four IES may be imposing that the referred SEP expand its range of activities and the offer of practices due to the lack of fields external to the IES.

Therefore, it is noted that the attendance model under the modality of individual psychotherapy and psychologic evaluation or psycho diagnosis prevails in the SEP of Rio Grande do Norte, and that the clinical area is prioritized, which is not new, considering the profile of the working fields of the Brazilian psychologist, with the dominance of the clinic area over the remaining. In addition, it is perceived a model that favors the individual clinic activities in Psychology formation, which in turn affects the professional identity of the Psychologist, restricting the possibilities of insertion in various contexts (Gondim, Bastos, \& Peixoto, 2010).

The few group activities recorded in the research follow the paradigm of individual care, focusing on psychotherapies. It is of worth to note that the modalities of the workshops, group discussions and staff meetings to discuss 
the unfolding of demands that arrive at the SEP started happening regularly by SEP 4 and sporadically by SEP 1 . These activities may represent the beginning of a change in formation, but it is still far from reaching the primary place that traditional practices occupy.

The predominance of inherent activities to clinic Psychology in these formation spaces impels us to question the guiding role of the National Curricular Guidelines for Psychology Courses, and above all, the influence of these practices of the psychologists in social policies, mainly of health and social assistance, that have been presented as spaces of increasing occupation by the Brazilian psychologist, according to Gondim et al. (2010). There is an urgent need that these contribute to the development of compatible competencies that prepare the student to operate in the context of these policies.

\section{Articulation of the University Services with the Social Assistance and Health Networks}

The results on the articulation of the SEP with the health and social assistance networks do not surprise us. Either by direct observation or by the answers of interns and graduates, we recorded that the manner of articulation between the SEP and the network devices of SUAS and SUS, however existent, are still fragile and informal, as far as part of the referrals is made verbally, and when written, many do not clarify on the reasons for requiring the service. It is observed that the manner of articulation is established, primarily, through the model of referral from SUS - of professional from the Basic and Specialized Health Units: ESF, Specialty Clinics, Psychosocial Attention Centers (CAPS), hospitals, among others; and of SUAS - CRAS, of CREAS, of the Casa $d a$ Familia, of the Casas de Passagem and of Child and Adolescent Tutelary Councils.

In turn, the SEP of $\mathrm{RN}$ receive the demands of the mentioned health and social assistance devices, performing especially individual attendances under the modality of psychotherapies. There is the record of some experiences with the qualification of Tutelary Council, groups of women, groups of individuals that carry severe mental disorders and their families, groups with children and their guardians, groups made with the educators of children and teenagers from the Casas de Passagem, among other experiences, which do not correspond to the modalities of activities that overlap, in a larger amount, psychotherapies and psychologic counseling.

The formation at the SEP of RN, by having the individual clinic activity as main activity, may influence the practices developed at SUS and SUAS. In a research, Oliveira, Solon, Amorim and Dantas (2011) recorded the existence of clinic activity as priority, in a significant amount of CRAS, in the metropolitan region of Natal, even it is not set by SUAS, especially in this kind of device. Also according to these researchers, from the 18 psychologists working at CRAS, 16 performed psychotherapies, tests, play therapies, among other modalities of clinic psychologic care.

In the item Articulation with health and social assistance networks, the majority of interns (36) answered that there is articulation, 17 that there is not and four did not mark any alternative. As to the graduates, the question was if any internship practices developed by the University Service/Clinic was compatible with the practices developed in public health and/or social assistance networks. From this total, 12 answered affirmatively, 7 that there is not and 1 that there was no practices compatible with the social assistance area and 5 did not answer.

When questioned about the modalities of this articulation, their answers refer, mostly, to the modality of referring services, from the networks to the SEP, or the other way around. The said referrals are primarily for psychotherapies and for psychologic evaluation. Other articulation modalities, appointed by the majority of interns and graduates (the amount between the parenthesis, below), were the discussions, meetings and qualifications performed along with the Tutelary Councils of the four administrative zones of the city, especially related to the psychologic care of victims of sexual abuse, referred by these institutions (10 mentions); the work made by 
interns in Casas de Passagem of children e teenagers (6 mentions); therapeutic monitoring (2 mentions); and matrix-based strategies of mental health care, this last one reported by only one participant of the research.

The Social Assistance Reference Centers (CRAS) and the Specialized Social Assistance Reference Center (CREAS) perform referrals to other services. Usually, the individuals are formally referred by the psychologist or another professional from the Centers for monitoring (psychotherapy, play therapy) and/or psychologic evaluation. In regard to the formation through the SEP to work in the public social policy, the research ratify what Oliveira et al. (2011) assert on the work of psychologists in this policy: ". . . Thus, the field of Social Assistance enables the psychologists to work in the fight against poverty, but the challenges of the own social policy and the obstacles that follow the history of the profession remain" (Oliveira et al., 2011, p. 140).

From what has been mentioned, we may identified that the articulation between the SEP and the assistance networks of SUS and SUAS still needs formalization. In regard to articulation, there is a lack of a shared accountability between both entities, bearing in mind that many times there is only one attendance, which is resumed to a referral, culminating in the shift of problems, for, in general, whoever refers the individual steps away from the responsibility of the case, or the situation, without using the appropriate instruments that enable the realization of the counter-referral. Who refers does not know of the unfolding of the case, nor they seek to know; whoever receives do not provide any information about the care.

Concerning the formalization of the SEP inside the public health and social assistance policies, it is identified that there is not an official recognition of the SEP as devices of the policies. That way, the relation between them is officious. The formal inclusion of the SEP in the assistance networks assume a formal relation between the agent institutions of health and social assistance policies (municipal secretariats); that the design of the network of each institution may include the SEP as one of the references; that SEP that meet the minimum standards required by SUS and/or SUAS, mainly, observing the principle of equity and the directive of regionalization.

The position that the SEP currently occupy prevents the attendance, for example, to the principle of integrality and the premises of humanization and interdisciplinarity inherent to the national health policy. Nor does it allow practices that focus the guarantee and the reestablishment of rights, in inter-sector articulations, in relation to SUAS. In this manner, the interns live little or almost nothing, in terms of complexity of the public policy systems, hindering the professional practice from the work inside a network.

\section{Contribution of the University Services for the Formation of Agreements with Interns}

The majority of the speech of the interns and graduates credits to the SEP a central importance to their formation. The "clinical vision"; the "psychotherapy competences"; the "hearing that is very singular to clinical space"; "the handling, the transfer/counter-transfer and implication" and the "clinical education" are references to Psychology that may limit the competences and abilities for the work in health and social assistance policies. In this perspective, the SEP have been forming the psychologists to work in the clinical area, what is possibly may be the reason why in Brazil "clinical work is the predominant working field for the psychologist, and it is extending for areas beyond particular offices and penetrating in public health institutions and inside the third sector" (Gondim et al., 2010, p. 197).

However, some of the speeches of interns that participated in the research highlight the importance of the SEP in the sense of providing the performing of activities in articulation with devices of health and social assistance networks. This scenario may represent an advancement, compared to the predominant model of SEP only as a university clinic. Usually, interns and graduates point that the activities and the mode of operation attend to their expectations. They justify their satisfaction affirming that the SEP provides a "theoretical and practical relation", "bringing 
to reality", as well as it improves "what has been learned in the classroom", "preparing the future professional", for the clinical practice, attending to "the needs of the interns and clients", "awakening autonomy and responsibility", attending to the low-income population and has the "support of experienced persons". These references reveal a comprehension of the importance of practice for professional exercise.

Other speeches indicate the "possibility to perform psychotherapy with a critical attitude"; "open to the amplified, though traditional clinic is predominant"; "it allows knowing more the clinic"; it allows "the contact with the various fields of work of the psychologist and various services". It makes available the "practices on different contexts"; "ethical formation and care with the human side"; it propitiates the development of "activities that theory has prepared"; the performance of "staff meetings" and develop "competences and to host doubts".

In regard to administrative aspects, it was evinced by interns "problems with the scheduling of rooms"; "errors with forms"; overload of interns by the higher level technicians or tutors of the SEP; "lacking communication between interns and professionals". Still, the weak interinstitutional articulation and the fact that the "employees could be more qualified, as well as having a larger variety of activities", were aspects indicated as unsatisfactory. In addition, the "short" period of internship; the "lack of specific rooms for the realization of psychologic evaluation"; the little articulation between the University Services and the health network and the gap inside the area of Work Psychology, at the "business consulting and professional orientation projects" were other poor aspects evaluated by the participants concerning the University Services.

The evaluation of SEP by the interns and graduates refers, therefore, to the possibility of practical exercise of the knowledge acquired in the classroom, as well as to the quality of supervisors and the good physical structure of the service. These results may provide the reflection, by managers and by the technical staff of forming institutions, about the need of formal incorporation of education strategies at the SEP that prioritize: (a) the development of abilities and competences to work at public policies (Yamamoto, 2003); (b) activities targeted to the guaranteeing and reestablishment of rights systems (Alberto, Freire, Leite, \& Gouveia, 2014); (c) practices that guarantee the maintenance of health care in the longitudinal and transversal dimensions (Dimenstein, 2014); and (d) jointly with the public health services (Spink, Brigadão, \& Nascimento, 2014).

A critical attitude begins to be developed by interns, when pointing the gaps in these establishments, which turn out to be "lacking", according to the following report from an intern:

It is lacking in clinic and social areas; it prioritizes the clinic, the individualized care, being far from other health community units, without sharing experiences, without sharing cases, finally, I believe that the clinic should be in contact with the remaining health services. (SEP 4 ES37)

In this way, the activities at the SEP, their participation in the formation process, still need an investment for the preparation of interns to work in public policies, though there are some movement in this direction. It is a matter of rethinking the formation for professional exercise from a concept of the role and the social commitment of the psychologist and its practices, giving place to a formation project that is interdisciplinary and that is in agreement with public policies.

\section{Final Considerations}

The four researched SEP have hybrid characteristics in which coexist the model of a University Clinic, focused in traditional institutional and psychologic practices, such as individual psychotherapy, the evaluation and the triage and the new modalities of action, the provision of community services, involving various agents, institutions and networks, particularly, of health and social assistance. Though they are poorly articulated and incipient, they already indicate a concern with the formulation of new premises for the work of the psychologist 
attuned with critical expertise on their own formation and the possibilities of interventions inside the reality that it is inserted. However, as mentioned before, the predominant characteristic is the operation in isolation from other academic and professional instances, with the absence of inter-disciplinary practices and technical tools to act in the field of public policies in agreement with the social and political demands of the Brazilian society. In this sense, it is note an informal and fragile relation between the University Services and the social assistance and health networks, which predominating practice is the two-way referral, without the establishment of effective partnerships, sustained by the co-responsibility and the continuity of care.

The increase of the numbers of Psychology courses in the country may be configured as one more concern with the practices of the University Services, especially if we consider the affirmation of Mello and Patto (2008) about the education institutions "that are nothing more than companies that sell Psychology courses focusing the profit, without having attention to the responsibility present in granting diplomas to professionals trained to say arbitrariness and absurd as if they were speaking unquestionable truths" (p. 593).

Though the quick changes in society may weigh, the changes in academic formation do not follow the rhythm and the reality of the researched courses is not different from the national reality. Following the analysis of Abbad and Mourão (2010), we consider that new competences for the insertion of psychologist in social assistance and health policies are not being developed in a satisfying manner in Psychology courses. We face the dominance of traditional formation focused on the isolated and individual work, with a gap in competences for teamwork and to work with socially vulnerably populations.

It is noted the scarcity of integrating practices, in the offering of group activities, of visits and home visits, family orientation, rights defense practices, community strengthening and empowering, and finally, of alternatives that surpass the common place occupied by Psychology. This perspective has been reinforced by the operation mode of local University Services, which have been little permeable to the incorporation of new working principles and action guidelines that inaugurate other social locations for the academic-professional formation spaces, as has been proposed by the experiences that articulate education-servicecommunity, with the use of various educationalpedagogical strategies. According to Medeiros, Fidelis, Pinto and Nuto (2011), "the articulation education-service-community, a strategy for the effectively integrating theory and practice, is, then, reached by the premature insertion of students in real and diversified scenarios of teaching and learning" (p. 29).

Such experiences have expanded the knowledge of health needs and problems from the population inside their territories, revealing the need to qualify professors in new teaching methods, as well as bringing together teachers and students with health, social assistance and community networks. There remains, then, one question: to what extent are we eager to make the University Services as scenarios to problematize the social place occupied by the psychologist, of reflection and intervention on existing conditions, on the production of subjects that insist in being outraged and fight for a Psychology that breaks from the hygienic, excluding, prejudiced and technical tendencies that still characterized our fields of knowledge and practices?

Thus, we agree with Yamamoto (2012), when he points that, "instead of qualifying the professional actions as socially compromised or not, we could think of the as linked or articulated to one or another ethical-political professional project" (p. 14). It is a project in which formation is not completely isolated from other professionals that act in public policies, especially, in the field of social security. Thus, it is worth to rethink the integrated SEP - not only in terms of space, but also of its practices - to other courses and these, in turn, to the networks of the social security service.

Finally, it is observed that, in general, the SEP of RN are still not following the National Curricular Directives, in what concerns to the expanding of the formation of the psychologist 
to work in various contexts. Furthermore, they still focus their activities in the formation of a liberal professional, away of public policies. Is it possible that Psychology courses from the IES of RN are limited to wait for the offer of internship vacancies at the public devices of social assistance and of health? With the increase of vacancies and Psychology courses, is it time that the SEP are inserted into these social policies networks?

\section{References}

Abbad, G. S., \& Mourão, L. (2010). Competências profissionais e estratégias de qualificação e requalificação. In A. V. B. Bastos \& S. M. G. Gondim (Eds.), O trabalho do psicólogo no Brasil (pp. 380-401). Porto Alegre, RS: Artmed.

Alberto, M. F. P., Freire, M. L., Leite, F. M., \& Gouveia, C. N. N. A. (2014). As políticas públicas de assistência social e atuação profissional. In I. F. Oliveira \& O. H. Yamamoto (Eds.), Psicologia e politicas sociais: Temas em debate (pp. 127-174). Belém, PA: Editora da Universidade Federal do Pará

Bardagi, M. P., Bizarro, L., Andrade, A. M. J., Audibert, A., \& Lassanc, M. C. P. (2008). Avaliação da formação e trajetória profissional na perspectiva de egressos de um curso de psicologia. Psicologia: Ciência e Profissão, 28(2), 304-315. doi:10.1590/S141498932008000200007

Bastos, A. V. B., \& Gomide, P. I. (1989). O psicólogo brasileiro: Sua atuação e formação profissional. Psicologia: Ciência e Profissão, 9(1), 6-15. doi:10.1590/S1414-98931989000100003

Bastos, A. V. B., \& Gondim, S. M. G. (Eds.). (2010). O trabalho do psicólogo no Brasil. Porto Alegre, RS: Artmed.

Bernardes, J. S. (2007). A psicologia no SUS 2006: Alguns desafios na formação. In M. J. P. Spink (Ed.), A psicologia em diálogo com o SUS. Prática profissional e produção acadêmica (pp. 105-127). São Paulo, SP: Casa do Psicólogo.

Bernardes, J. S. (2010). A psicologia no SUS 2006: Alguns desafios na formação. In M. J. P. Spink (Ed.), A psicologia em diálogo com o SUS: Prática profissional e produção acadêmica $\left(2^{\text {nd }}\right.$ revised reprint, pp. 105-127). São Paulo, SP: Casa do Psicólogo.
Bernardes, J. S., \& Menegon, V. S. M. (2007). Documentos de domínio público como produtos e autores sociais. Psico, 38(1), 11-15.

Boeckel, M. G., Krug, J. S., Lahm, C. R., Ritter, F., Fontoura, L. O., \& Sohne, L. C. (2010). O papel do serviço-escola na consolidação do projeto pedagógico do curso de Psicologia. Psicologia: Ensino \& Formação, 1(1), 41-51.

Ceccim, R. B., \& Feuerwerker, L. C. M. (2004). O quadrilátero da formação para a área da saúde: Ensino, gestão, atenção e controle social. Physis: Revista de Saúde Coletiva, 14(1), 41-65.

Conselho Federal de Psicologia. (Ed.). (1988). Quem é o psicólogo brasileiro? São Paulo, SP: Edicon.

Conselho Federal de Psicologia. (Ed.). (1992). Psicólogo brasileiro: Construção de novos espaços. Campinas, SP: Átomo.

Conselho Federal de Psicologia. (Ed.). (1994). Psicólogo brasileiro: Práticas emergentes e desafios para a formação. São Paulo, SP: Casa do Psicólogo.

Conselho Nacional de Educação, Câmara de Educação Superior (2004). Resolução $n$. 8 , de 7 de maio de 2004. Retrieved from http://webcache.googleusercontent.com/ search?q=cache:http://portal.mec.gov.br/ cne/arquivos/pdf/rces 08 _04.pdf\&gws_ $\mathrm{rd}=\mathrm{cr} \& \mathrm{ei}=\mathrm{Z5q}$ qoV8RWhKCBPDPhsgD

Dimenstein, M. (1998). O psicólogo nas unidades básicas de saúde: Desafios para a formação e atuação profissionais. Estudos de Psicologia (Natal), 3(1), 53-81. doi:10.1590/S1413294X1998000100004

Dimenstein, M. (2000). A cultura profissional do psicólogo e o ideário individualista: Implicações para a prática no campo da assistência pública à saúde. Estudos de Psicologia (Natal), 5(1), 95121. doi:10.1590/S1413-294X2000000100006

Dimenstein, M. (2014). A psicologia no campo da saúde mental. In I. F. de Oliveira \& O. H. Yamamoto (Eds.), Psicologia e políticas sociais: Temas em debate. Belém, PA: Editora da Universidade Federal do Pará.

Dimenstein, M., \& Macedo, J. P. (2010). Desafios para o fortalecimento da psicologia no SUS: A produção referente à formação e inserção profissional. In M. J. P. Spink (Ed.), A psicologia em diálogo com o SUS: Prática profissional e produção acadêmica (2. reimpressão rev., pp. 207-234). São Paulo, SP: Casa do Psicólogo. 
Dimenstein, M., \& Macedo, J. P. (2012). Formação em Psicologia: Requisitos para atuação na atenção primária e psicossocial [Número especial]. Psicologia: Ciência e Profissão, 32, 232-245. doi:10.1590/S1414-98932012000500017

Gondim, S. M. G., Bastos, A. V., \& Peixoto, L. S. A. (2010). Áreas de atuação, atividades e abordagens teóricas do psicólogo brasileiro. In A. V. B. Bastos \& S. M. G. Gondim (Eds.), O trabalho do psicólogo no Brasil (pp. 174-199). Porto Alegre, RS: Artmed.

Law n. 4.119, de 27 de agosto de 1962. (1962, December 17). Dispõe sôbre os cursos de formação em psicologia e regulamenta a profissão de psicólogo. Diário Oficial da União. Retrieved from http://www.planalto.gov.br/ ccivil_03/ leis/1950-1969/ L4119.htm

Lo Bianco, A. C., Bastos, A. V. B., Nunes, M. L. T., \& Silva, R. C. (1994). Concepções e atividades emergentes na psicologia clínica: Implicações para a formação. In Conselho Federal de Psicologia (Ed.), Psicólogo brasileiro: Práticas emergentes e desafios para a formação (pp. 7-76). São Paulo, SP: Casa do Psicólogo.

Macedo, J. P. S., \& Dimenstein, M. (2011). Formação do psicólogo para a saúde mental: A psicologia piauiense em análise. Interface - Comunicação, Saúde, Educação, 15(39), 1145-1157. doi:10.1590/S1414-32832011005000021

Malvezzi, S. (2010). A profissionalização dos psicólogos: Uma história de promoção humana. In A. V. B. Bastos \& S. M. G. Gondim (Eds.), O trabalho do psicólogo no Brasil (pp. 17-31). Porto Alegre, RS: Artmed

Marturano, E. M., Silvares, E. F. de M., \& Oliveira, M. da S. (2014). Serviços-escola de psicologia: Seu lugar no circuito de permuta do conhecimento. Temas em Psicologia, 22(2), 457-470. doi:10.9788/TP2014.2-15

Maturana, H. (2005). Emoções e linguagem na educação e na política. Belo Horizonte, MG: Universidade Federal de Minas Gerais.

Medeiros, M. A. S., Fidelis, G. M. A., Pinto, W. M., \& Nuto, S. de A. S. (2011, dez.). Integração Ensino-Serviço e Atenção Farmacêutica. Caderno FNEPAS, 1 .

Mello, S. L. de, \& Patto, M. H. S. (2008). Psicologia da violência ou violência da psicologia? Psicologia USP, 19(4), 591-594. doi:10.1590/S010365642008000400013
Melo-Silva, L. L., Santos, M. A., \& Simon, C. P. (2005). Serviço-Escola em Psicologia: A construção do saber prático. In L. L. Melo-Silva, M. A. Santos, \& C. P. Simon, Formação em Psicologia - Serviços-escola em debate (pp. 21-30). São Paulo, SP: Vetor.

Mendes, N. M. (n.d.). Histórico da Psicologia no RN e a organização da categoria no Conselho de Psicologia. In Conselho Regional de Psicologia da $17^{\mathrm{a}}$ Região - Rio Grande do Norte, Histórico. Retrieved from http://www.crprn.org.br/institucional/historico/

Menicucci, T. M. G. (2002). Intersetorialidade: O desafio atual para as políticas sociais. Pensar $\mathrm{BH}$. Politica Social, 3, 0-13.

Ministério da Educação. (2011). Resolução n. 5, de 15 de março de 2011. Retrieved from http:// portal.mec.gov.br/index.php?option $=\mathrm{com}_{-}$ docman\&view $=$ download\&alias $=7692-\mathrm{rc}-$ es005-11-pdf\&category_slug=marco-2011pdf\&Itemid $=30192$

Noronha, A. P. (2003). Docentes de psicologia: Formação profissional. Estudos de Psicologia (Natal), 8(1), 169-173. doi:10.1590/S1413294X2003000100019

Nunes, M. L. T., Campezatto, P. V. M., Cruxên, O. S., \& Savalhia, J. A. D. (2006). Clínicas-escola de psicologia e psicoterapia psicanalítica: O duplo desafio de atender com qualidade à clientela e propiciar ao acadêmico uma boa formação. In B. Werlang \& M. Oliveira (Eds.), Temas em psicologia clínica (pp. 36-45). São Paulo, SP: Casa do Psicólogo.

Oliveira, I. F., Solon, A. F. A. C., Amorim, K. M. O., \& Dantas, C. M. B. (2011). A prática psicológica na proteção social básica do SUAS [Número especial]. Psicologia \& Sociedade, 23, 140-149. doi:10.1590/S0102-71822011000400017

Oliveira, M. S., Pereira, R. F., Peixoto, A. C. A., Rocha, M. M., Oliveira-Monteiro, N. R., Macedo, M. M. K., \& Silvares, E. F. M. (2014). Supervisão em serviços-escola de psicologia no Brasil: Perspectiva dos supervisores e estagiários. Psico, 45(2), e1-e9. doi:10.15448/19808623.2014.2.15417

Paulin, T., \& Luzio, C. A. (2009). A Psicologia na Saúde Pública: Desafios para a atuação e formação profissional. Revista de Psicologia da UNESP, 8(2).

Pazeto, A. E. (2005). Universidade, formação e mundo do trabalho: Superando a visão corpora- 
tiva. Ensaio: Avaliação e Politicas Públicas em Educação, 13(49), 487-496. doi:10.1590/S010440362005000400006

Romaro, R. A., \& Capitão, C. G. (2003). Caracterização da clientela da clínica-escola de Psicologia da Universidade São Francisco. Psicologia: Teoria e Prática, 5(1), 111-121.

Silvares, E. F. M. (1996). É satisfatório o atendimento psicológico nas clínicas escolas brasileiras? In R. M. L. Carvalho (Ed.), Coletâneas da ANPEPP: Vol. 9. Repensando a formação do psicólogo: Da informação à descoberta (pp. 137-145). Campinas, SP: Alínea.

Silvares, E. F. M. (Coord.). (2008). O atendimento psicológico nas clínicas-escola: Convergências atuais (2008-2009). In J. Q. Pinheiro \& F. S. Albuquerque (Eds.), Anais do XII Simpósio de Pesquisa e Intercâmbio Cientifico da ANPEPP: Conhecimento em Psicologia no Brasil: Expansão e avaliação. Retrieved from http://www.anpepp.org.br/old/XIISimposio/XII-GTs/GT_30_ AtendPsicologicoClinicasEscola.pdf

Silvares, E. F. M. (Ed). (2006). Atendimento psicológico em clínicas-escola. Campinas, SP. Alínea.

Spink, M. J. P. (2003). Psicologia social e saúde: Práticas, saberes e sentidos. Petrópolis, RJ: Vozes.

Spink, M. J. P., Brigadão, J. I. M., \& Nascimento, V. L. V. (2014). Psicólogos(as) no SUS: A convivência necessária com as políticas de saúde. In I. F. Oliveira \& O. H. Yamamoto (Eds.), Psicologia e políticas sociais: Temas em debate (pp. 9-243). Belém, PA: Editora da Universidade Federal do Pará.

Yamamoto, O. H. (2001). Espaços, práticas: O que há de novo na psicologia no Rio Grande do Norte? Psicologia em Estudo, 6(2). doi:10.1590/S141373722001000200009
Yamamoto, O. H. (2003). Questão social e políticas públicas: Revendo o compromisso da psicologia. In A. M. B. Bock (Ed.), Psicologia e o compromisso social (pp. 37-53). São Paulo, SP: Cortez.

Yamamoto, O. H. (2007). Políticas sociais, "terceiro setor" e "compromisso social": Perspectivas e limites do trabalho do psicólogo. Psicologia \& Sociedade, 19(1), 30-37. doi:10.1590/S010271822007000100005

Yamamoto, O. H. (2012). 50 anos de profissão: Responsabilidade social ou projeto éticopolítico [Número especial]? Psicologia: Ciência e Profissão, 32. doi:10.1590/S141498932012000500002

Yamamoto, O. H., Dantas, C. M. B., Costa, A. L. F., Alverga, A. R., Seixas, P. S., \& Oliveira, I. F. (2003). A profissão de psicólogo no Rio Grande do Norte. Interação, 7(2), 23-30.

Yamamoto, O. H., \& Oliveira, I. F. (2011). Política Social e Psicologia: Uma trajetória de 25 anos [Número especial]. Psicologia: Teoria e Pesquisa, 26. doi:10.1590/S0102-37722010000500002

Yamamoto, O. H., Siqueira, G. S., \& Oliveira, S. C. C. (1997). A Psicologia no Rio Grande do Norte: Caracterização geral da formação acadêmica e do exercício profissional. Estudos em Psicologia (Natal), 2(1), 42-66.
Recebido: 06/04/2015

$1^{a}$ revisão: 06/08/2015

$2^{a}$ revisão: $25 / 09 / 2015$

Aceite final: 12/10/2015 